\title{
Między zakorzenieniem w dziedzictwie tradycji a otwartością (na) pogranicza. O kształtowaniu „międzykulturowej tożsamości” i tropach pedagogicznych poszukiwań Jerzego Nikitorowicza
}

Streszczenie: Wypracowując koncepcję pedagogiki międzykulturowej i koncepcję „międzykulturowej tożsamości”, Jerzy Nikitorowicz rozpatruje doświadczenie zakorzenienia w tradycji i postawę „człowieka pogranicza” (otwartego na odmienności kulturowe). Towarzyszy temu świadomość napięć właściwych dynamice pogranicza. W sytuacji pogranicza coś może być „zarazem” tym, czym jest (co ma określony kształt tożsamości) i „zarazem” czymś innym, czymś z pogranicza jednego i drugiego (lub też trzeciego, kolejnego) jestestwa. Obeznanie w złożoności pogranicza w jakiejś mierze przygotowuje na zetknięcie się z zapatrywaniami innymi niż własne, które jawią się jako nieoczywiste (a trzeba z nimi konfrontować własne oczywistości, ryzykując, iż to one staną się problematyczne). Pogranicza nie są „gdzieś daleko”, „na kresach”, ale ich obecność i ich cechy, m.in. dynamiczne układy wartości, wpisują się w różne obszary człowieczej egzystencji, kształtując rozumienie podstawowych „spraw ludzkich”. Zmierzając do dojrzałych teoretycznie ujęć problematyki Innego, pogranicza i relacji międzykulturowych, Nikitorowicz postuluje rewitalizację heterologii (nauki i wiedzy o Innym).

Słowa kluczowe: zakorzenienie, dziedzictwo tradycji, otwartość, pogranicza, pedagogika międzykulturowa, „międzykulturowa tożsamość”

Człowiekowi trudno żyć w izolacji i naturalna jego potrzeba jest konieczność zakorzenienia się, zadomowienia, zagospodarowania i oswojenia przestrzeni życia. Jerzy Nikitorowicz (2000, s. 14)

[...] edukacja międzykulturowa w perspektywie antropologicznejtak jak jest rozwijana przez Tadeusza Lewowickiego i Jerzego Nikitorowicza to teoria i praktyka edukacji, obejmujaca refleksje naukowa i [...] [dziatania] umożliwiajace przygotowanie ludzi [...] różnych kultur do wspótistnienia. Alina Szczurek-Boruta (2011, s. 144) 
[Jerzy Nikitorowicz] systematycznie rozwija $w$ swojej białostockiej szkole naukowej studia i badania międzykulturowe. Poczynania badawcze [...] [Nikitorowicza] ukierunkowane sa [także] [...] oryginalna własna propozycja teoretyczna [...]. Teoria wielozakresowej $i$ wielowymiarowej tożsamości (TWiWT) jest ważna pedagogiczna perspektywa $w$ [...] [badaniach] kształtowania się poczucia tożsamości w warunkach wielokulturowości oraz [...] środowisk zróżnicowanych kulturowo. Ewa Ogrodzka-Mazur (2017, s. IV)

Koncepcja wielopłaszczyznowej i ustawicznie kreujacej się tożsamości J. Nikitorowicza zaktada nieustanny proces ksztattowania i funkcjonowania tożsamości w triadzie: tożsamość dziedziczona - tożsamość nabywana w procesie socjalizacji tożsamość wybierana „Ja. [...] [J. Nikitorowicz] wskazuje na potrzebę ksztaltowania tożsamości międzykulturowej. Alina Szczurek-Boruta (2017, s. 196)

Zasadniczym punktem wyjścia i stałym punktem odniesienia dla pedagogicznych poszukiwań Jerzego Nikitorowicza jest doświadczenie zakorzenienia/ zakorzeniania się w dziedzictwie własnej tradycji, będące zarazem - co w tym przypadku szczególnie istotne - doświadczeniem „człowieka pogranicza”. Dążąc do wypracowania teoretycznie dojrzałej i praktycznie przydatnej postaci pedagogiki międzykulturowej oraz nieredukcjonistycznej koncepcji „międzykulturowej tożsamości”, Nikitorowicz afirmuje postawę „człowieka pogranicza”, otwartego na to, co niesie z sobą odmienność kultur, religii i języków, ukazując wzorce tej pożądanej postawy. Tej afirmacji towarzyszy wszakże wyostrzona świadomość, że „człowiek pogranicza” powinien kształtować i rozwijać w sobie umiejętność wnikliwego, krytycznego i roztropnego rozeznawania różnego typu antagonistycznych i konfliktogennych napięć, których trudno uniknąć w złożonej sytuacji (dynamice procesów) pogranicza ${ }^{1}$.

1 „Konflikt kulturowy może istnieć w świadomości jednostki w całym procesie życiowym, jednak nie musi wytworzyć antagonistycznej ideologii i wrogich nastawień” (Nikitorowicz, 2015b, s. 39). „[...] w edukacji międzykulturowej akcentowane są z jednej strony dążenie do sytuacji spotkania [...] [i] dialogu, z drugiej - wymóg respektowania zasady nieredukowalnej różnicy, szukania sposobów konstruktywnego wychodzenia z konfliktów" (Olbrycht, 2019, s. 243). O rozumieniu roli konfliktów zob. (Szczurek-Boruta, 2009, ss. 125-138); (Jasiński, 2009, ss. 139-151); (Szczepański, Śliż, 2012, ss. 11-27); (Mucha, 1992, ss. 65-78). 
Doświadczenie „człowieka pogranicza”, zmierzającego do rozwinięcia i refleksyjnego uwyraźnienia swej - niejako w zarodku posiadanej - „międzykulturowej tożsamości”, sytuuje się w napięciu między zakorzenieniem/ zakorzenianiem się w tradycji a otwartością (na) pogranicza. O silnie aksjologicznie nasyconym dziedzictwie tradycji powinno się myśleć nie tylko retrospektywnie (o spetryfikowanych reliktach z przeszłości), ale recentywistycznie $^{2}$ i prospektywnie: jako o dokonującej się teraz transmisji różnego rodzaju i różnej mocy wartości, które obecnie wymagają aktualizacji i ich urzeczywistniania; jako o przekazie wartości, który wytwarza zobowiązania do zreflektowanego przyjęcia, kultywowania i odczytywania na nowo dziedziczonego świata wartości (niezredukowanego do biernej reprodukcji minionej postaci świata), przekazie teraz współokreślającym wewnętrznie zróżnicowaną tożsamość jednostki i zbiorowości. Przekaz i przyswajanie dziedziczonych wartości, wymagające postawy aktywnej i wręcz ustawicznego aktualizowania w zmieniającej się rzeczywistości, pozostają w twórczym napięciu z - dynamizującym dziedzictwo wartości - otwarciem się na zróżnicowanie kulturowe pogranicza; a bywa, że jest to otwarcie radykalne, nawet w pewnym sensie kosmopolityczne. Dzięki temu twórczemu napięciu - napięciu między zakorzenieniem w świecie dziedziczonych wartości a otwartością na inność i jej wartości - pobudzane są procesy i akty „ustawicznego kształtowania wielozakresowej i wielowymiarowej tożsamości”’3, postrzeganej jako pożądana postać „międzykulturowej tożsamości”. Mierzący się z palącymi - w tym aksjologicznymi i edukacyjnymi - wyzwaniami złożonej, zmiennej i niepoddającej się prostym klasyfikacjom rzeczywistości, „człowiek pogranicza" balansuje, aby utrzymać się w stanie chybotliwej równowagi.

2 Od łacińskiego słowa recens (niedawny, świeży) wskazującego na teraźniejszość (teraz); recentiore - najnowszy. Można przywołać heurystycznie płodne idee recentywizmu, akcentujące teraz (doniosłość tego, co wydarza się w teraźniejszości), które rozwijał Józef Bańka (1934-2019). „W wyniku dokonujących się zmian jesteśmy skazani na ciągłe określanie siebie w teraźniejszości na bazie przekazu wartości z przeszłości, z jednoczesnym wskazaniem perspektyw przyszłości, aby nie nastąpił zanik pamięci i transmisji tradycji" (Nikitorowicz, 2017a, s. 351). Problematykę czasu i kategorii interkulturowych rozpatruje Marek Szulakiewicz (Szulakiewicz, 2011).

3 Rozbudowany wykład koncepcji „ustawicznego kształtowania wielozakresowej i wielowymiarowej tożsamości" przedstawia (Nikitorowicz, 2017a, ss. 327-364). Zob. (Nikitorowicz, Żyłkiewicz-Płońska, 2017, ss. 9-20).

4 O różnych międzykulturowych typach tożsamości zob. (Paleczny, 2019, ss. 11$-33)$. 
Balansuje między odmiennymi i opozycyjnymi opcjami tożsamościowymi (opcjami etnicznymi, religijnymi, ideowymi, gospodarczo-ekonomicznymi), które - zamykając się w sobie i definiując w ostatecznej postaci „prawdziwą tożsamość" - mogą przyjąć postać wykluczających się i zwalczających opcji. „Człowiek pogranicza” cały czas rozwija zdolność balansowania w sytuacjach napięć, obarczonych ryzykiem tożsamościowej autodestrukcji i nawet samozatraty, jeśli naruszy się - „podcinając korzenie” - konstytutywne elementy autoidentyfikacji, pozbawiając ją relacji z tym, co ją podtrzymuje i wzmacnia.

Ta sytuacja „między”, właściwa doświadczaniu wartości przez „człowieka pogranicza” i kształtowaniu „międzykulturowej tożsamości”, wymaga m.in. "pochwały niekonsekwencji”". Wymaga jej wówczas, gdy postępowanie wedle zasad „żelaznej konsekwencji” (zespolonej z dążeniem do „pełnej przejrzystości" reguł postępowania) skutkować może destrukcyjnym zaślepieniem na osobliwości, walory i subtelności doświadczeń „człowieka pogranicza”, otwartego na cechujące się dynamiką i napięciami zróżnicowanie kultur, religii i języków. W wielowymiarowej i wielowarstwowej sytuacji pogranicza coś może bowiem być „zarazem”, „jednocześnie” i „równocześnie”: zarazem

5 Nawiązuję tu do tytułu i tez z tekstu (z 1958 roku) „Pochwała niekonsekwencji”, w którym Leszek Kołakowski (1927-2009) przez niekonsekwencję, będącą „utajoną świadomością sprzeczności świata”, rozumie „odmowę raz na zawsze przesądzającego wyboru między jakimikolwiek wartościami alternatywnie się wykluczającymi”, bowiem „przeciwieństwa te są immanentne światu wartości i nie mogą zostać pogodzone w żadnej syntezie harmonizującej" (Kołakowski, 1989, ss. 156-157); przy czym dodaje: „Bądźmy tedy niekonsekwentni również w samej niekonsekwencji [...], stosujmy zasadę niekonsekwencji do niej samej" (s. 160). Walory niekonsekwencji Kołakowski rozważa też w wywiadzie z 2004 roku: „Jeśli ktoś [...] marzy o doskonałości, [...] poucza, [...], daje lekcje innym [...], [jest] nieustannym poprawiaczem i nauczycielem. To [...] zły sposób na życie. Trzeba więc chyba iść na kompromisy ze sobą i światem. [...] dobra ważne w życiu często się kłócą ze sobą. [...] nie ma żadnej niezawodnej hierarchii wartości. Gdybym wierzył, że jest taka hierarchia, to dążyłbym do uznania jakiejś wartości za absolut i unieszczęśliwiałbym innych [...] i siebie [...]”. I dalej: „Przyjaźń, która jest dobrem, i nepotyzm, który jest złem, dzieli granica miary. Ale to też nie jest żadna ostra granica. [...] Nie ma ostrych granic. W żadnej najsłuszniejszej sprawie nie warto popadać $\mathrm{w}$ fundamentalizm [...]. [Zasady] niepodlegające korekcie, niedające się zmiękczyć - to przeważnie nie są zasady zbyt mądre. Mądre zasady nigdy nie są absolutne. Bo w życiu prawie nigdy nie zdarzają się sytuacje, w których nic się nie liczy oprócz jednej rzeczy. [...] Nie ma jednoznaczności w świecie". W wywód jest wtrącona uwaga: „(bo w życiu wszystko ma drugą stronę)” (Kołakowski, 2004). Zarazem Kołakowski nie głosi relatywizmu odrzucającego prawdę, stwierdza: „[...] gdy nie ma czegoś takiego jak prawda, nie ma również miejsca na wątpienie" (Kołakowski, 1990, s. 37). 
tym, czym jest (co ma swe granice, ma określony kształt tożsamości) i zarazem w jakiejś mierze czymś innym, czymś z pogranicza jednego i drugiego (lub też trzeciego, kolejnego) jestestwa. Coś się ukazuje z jednej, ale zarazem i z drugiej strony, odsłaniając inne oblicza. Rwie się oczekiwana ciągłość narracji i pewność co do jednoznaczności jej przekazu, nie jest ona „po prostu” konsekwentna, wchodzą niespodziewane wątki i punkty odniesienia, które wprowadzają nowe konteksty interpretacyjne. Choć zdaje się, że mimo wielorakich nieciągłości tej narracji ma ona w sobie ukrytą spójność, jest zanurzona w ogarniającej ją - choć nieprzenikliwej - metanarracji, która pozwala domniemywać, iż są - jako spoiwo - nieuwidocznione i niedopowiedziane przejścia między tymi niby rwącymi się i wolno snującymi wątkami. W doświadczeniu pogranicza zdają się zawarte - konstytutywne - momenty trudne do jednoznacznego wyartykułowania, zwłaszcza w języku ukształtowanym poza pograniczem (ujednoznacznionym w kulturowo jednorodnym środowisku ze zuniformizowanym obrazem świata i zunifikowanym układem wartości), a nawet przejawiają się momenty apofatyczne, gdy znaczące zamilknięcie bywa pożądaną postawą. Mając obeznanie w polifoniczności warunków pogranicza, jest się w jakiejś mierze duchowo i intelektualnie przygotowanym na (pobudzające do refleksji) zetknięcie się ze zróżnicowaniem i pluralizmem zapatrywań innych niż własne ${ }^{6}$. Te inne zapatrywania, wyrażające różne treści, zwłaszcza dotyczące wartości, jawią się w dużej mierze jako nieoczywiste, jako reprezentujące odmienny - co więcej: trudny do zrozumienia i akceptacji - punkt widzenia, dlatego z tym, co jawi się jako nieoczywiste, trzeba rzetelnie skonfrontować własne oczywistości, ryzykując, iż to one staną się mocno problematyczne i stracą przypisywane im znamię oczywistości.

W dyskursie charakterystycznym dla refleksji pedagogicznej Nikitorowicza, zwłaszcza w dociekaniach dotyczących szeroko zakreślonego spektrum różnych aspektów problematyki tożsamości, zakorzenienia, pogranicza i edukacji międzykulturowej, częstokroć występuje „zarazem”, „jednocześnie” i „równocześnie”, a w narracji dokonują się zaskakujące „zwroty akcji” w inną stronę. Dociekania dynamicznie oscylują między rysującymi się możliwo-

6 „Pluralizacja systemów wartości, postaw [...] prowadzi do zwiększenia zakresu akceptowanej ich różnorodności, jednocześnie rodząc napięcia egzystencjalne wzbudzane koniecznością dokonywania wyborów, świadomością nieoczywistości, [...] dekompozycji istniejących form życia społecznego. Wielość konwencji i nieokreśloność kodów komunikacyjnych wymaga [...] [nowych] kompetencji komunikacyjnych" (Nikitorowicz, 2005, s. 15). 
ściami odmiennych podejść i między różnymi aspektami - wręcz różnymi obliczami - danego stanu rzeczy. Trzeba więc wytrwale prowadzić zmagania intelektualne $\mathrm{z}$ niedostatkami wyrobienia władz poznawczych, aby nie ulec dezorientacji poznawczej, aby nie nabyć wyuczonej bezradności i nie poddać się jej w sytuacji niepewności, aby nie skapitulować poznawczo przed wielowymiarowością rzeczywistości pogranicza i nie próbować sprowadzać jej redukcjonistycznymi zabiegami do "swojsko brzmiących” i łatwych w użyciu formułek, które (jak magiczne zaklęcia) mają dawać poczucie poznawczego i praktycznego panowania nad nią.

Edukacja międzykulturowa ${ }^{7}$ przedstawiana jest przez Nikitorowicza jako interesująca poznawczo i doniosła praktycznie sytuacja problemowa, która stawia kolejne, piętrzące się wyzwania badawcze i uczy badacza pokory w intelektualnych zmaganiach: „Na konferencjach [...] Zespołów Badań Pogranicza pojawiały się nowe problemy, nabieraliśmy [...] pokory do trudnych [...] zagadnień, zauważaliśmy jak niewiele ciągle potrafimy [...]. To niedookreślenie wielu spraw mobilizowało do [...] poczynań badawczych, kształtowało kontakty z innymi ośrodkami [...] [i] wzajemne wzbogacanie. Ostatnie lata [...] uświadomiły nam trudności [...] odpowiedzi na [...] pytania o aksjologie współczesności" (Nikitorowicz, 2000a, s. 46).

Argumentując, że wielokulturowość w różnych postaciach stanowi wielowymiarowy i narastający proces społeczny, budzący też pytania aksjologiczne, który należy uwzględniać w edukacji, Nikitorowicz promuje pogląd o powinności wypracowania strategii umożliwiających „kształtowanie odpowiednich kompetencji i postaw kulturowych na poziomie mikro i makro (z jednej strony [...] kształtowanie poczucia podmiotowości, [...] sprawstwa, wolności i odpowiedzialności, z drugiej - solidarności i demokratyzacji życia społecznego oraz integracji wobec ogólnoludzkich i ponadczasowych war-

7 „[...] edukacja międzykulturowa powoli zyskuje coraz większe zrozumienie. Przechodzi ona od [...] wielości do interakcji kultur. Jej celem nie jest budowanie zunifikowanej kultury globalnej, lecz poszerzanie własnej tożsamości jednostkowej i społecznej przez kontakt z innymi kulturami oraz propagowanie postaw tolerancji i dialogu” (Szczurek-Boruta, 2011, s. 142). „[...] w edukacji międzykulturowej różnicę i inność [...] traktujemy jako kapitał kulturowy, kapitał, którym człowiek dysponuje, z którego może wybierać" (Nikitorowicz, 2015b, ss. 26-27). O rozwoju edukacji międzykulturowej zob. m.in. (Lewowicki, 2000, ss. 21-35); (Lewowicki, 2017, ss. 19-36; (Nikitorowicz, 2011b, ss.7-18); (Nikitorowicz, 2015b, ss. 25-40); (Śliwerski, 1998, ss. 289-290); (Grzybowski, 2007); (Ogrodzka-Mazur, 2018, ss. 65-82); (Rusek, 2019, ss. 23-39); (Rembierz, 2019, ss. 40-56). 
tości)" (Nikitorowicz, 2000b, s. 37). Jest to holistyczne ujęcie dążeń pedagogiki międzykulturowej do rozwijania pożądanych przymiotów uczestników działań edukacyjnych, którzy są (będą) uczestnikami relacji międzykulturowych ${ }^{8}$. Wśród tych przymiotów eksponuje się walory podmiotowego sprawstwa i ich pozytywne moralnie własności (m.in. wolność i odpowiedzialność). Zostały także uwzględnione społeczne uwarunkowania (m.in. solidarności, demokratyzacji) i mocne aksjologiczne odniesienia, przekraczające lokalną grę interesów i uzyskanie doraźnych korzyści ${ }^{9}$ : sprawa respektowania przez uczestników relacji międzykulturowych wartości, które z istotnych powodów - przekraczania doraźnych, utylitarnych ograniczeń i ukazywania doniosłego egzystencjalnie znaczenia transcendentnych horyzontów - określa się jako "ogólnoludzkie i ponadczasowe"10.

Podejmując - obecnie na wiele sposobów formułowane - pytanie: „Czy współczesna wielokulturowość tworzy przestrzeń, w której różne wspólnoty i kultury wchodzą wzajemnie w interakcje, poznają się [...], [tworzą społeczeństwo, ze] wspólnymi wartościami i szacunkiem do jednoczącego dane społeczeństwo prawa?", Nikitorowicz udziela krytycznej i sceptycznej odpowiedzi: „idee wielokulturowości przeżywają kryzys [...] [w kontekście] zasad liberalizmu, relatywizmu kulturowego i poprawności politycznej, które [...] prowadzą do wykluczania tożsamościowego i marginalizacji nie tylko imigrantów, ale także obywateli kraju ich przyjmującego" (Nikitorowicz, 2014a, s. 173-174) ${ }^{11}$. Bardzo krytycznej ocenie poddane są przekonania ide-

8 O rozumieniu wielokulturowości i relacji międzykulturowych zob. (Korporowicz, 1997, ss. 64-72); (Śliz, Szczepański, 2015, ss. 13-27); (Śliz, 2017).

9 Nikitorowicz ostrzega przed groźbą instrumentalizacji różnic kulturowych, wykorzystanych „[...] jako środek mobilizacji i [...] realizacji partykularnych interesów” (Nikitorowicz, 2003, s. 53).

10 Co do wartości ogólnoludzkich czy ponadkulturowych zob. (Stróżewski, 2013, ss. 361-388); (Lewowicki, 2013, ss. 25-26); (Olbrycht, 2000); (Ogrodzka-Mazur, 2007); (Wiśniewski, 2016, ss. 597-612); (Kostkiewicz, 2017, ss. 31-44); (Rembierz, 2018, ss. 90-130); (Mariański 2019, ss. 203-312).

11 „Bezrefleksyjne posługiwanie się kanonem relatywizmu i politycznej poprawności, uznanie wszystkich kultur za równe [...] było reakcją na negatywne zjawiska hegemonii, kolonializmu [...]” (Nikitorowicz, 2014a, s. 174); „polityka wielokulturowości [...] [była] źle prowadzona. Domagano się [...] przywilejów dla pewnych grup etnicznych [...]. Stąd gettoizacja w imię kultywowania kultury [...], negowanie potrzeby nauczania języka kraju, w którym żyją imigranci [...], uznając, że byłby to rasizm, obraza ich godności [...]" (Nikitorowicz, 2014b, s. 13). Nikitorowicz postuluje roztropną stanowczość: „Jestem przekonany o potrzebie [...] konsekwencji, [...] ustalenia zasad 
owe i zinstytucjonalizowane (w systemie oświaty) sposoby działania, które skutkują kulturowym wykorzenianiem i zanikiem tożsamościowotwórczej refleksyjności.

\section{Etnocentryzm świata zakorzenienia a kształtowanie „mię- dzykulturowej tożsamości”}

W teorii wielozakresowej i wielowymiarowej tożsamości za niejako naturalny stan rzeczy w procesach kulturotwórczych i punkt odniesienia dla kształtowania „międzykulturowej tożsamości” przyjmuje się „etnocentryzm świata zakorzenienia”, określany jako „etnocentryzm świata oswojonego” (Nikitorowicz, 2011b, s. 9) ${ }^{12}$, na plan pierwszy wysuwający „zakorzenienie w świecie oswojonym, afirmację kultury rodzimej" (Nikitorowicz, 2003, s. 59). Jest to „etnocentryzm naturalny, wynikający z osadzenia kulturowego, z przejmowanego dziedzictwa, z pierwszej socjalizacji, naturalny proces nabywania kompetencji kulturowych, uczenia się kultury nieświadomie poprzez »zanurzenie« w niej i »nasiąkanie« jej wartościami” (Nikitorowicz, 2011b, ss. 9-10) ${ }^{13}$. Jeśli w refleksji pedagogicznej uwzględnia się wątpliwości podnoszone w nurtach ideowych bliskich kosmopolityzmu, to warto też zastanowić się: „Czy etnocentryzm [...] łączyć [tylko] z [...] uprzedzeniami,

i realizowania ich przez obie strony [...]. Taka stanowczość [...] [dotyczyła] zakazu noszenia chust islamskich we francuskich szkołach publicznych [...] i protesty środowisk islamskich wygasły. [...]. Od kilku lat w berlińskiej szkole średniej Herberta Hoovera o dużej liczbie imigrantów, głównie Turków, należy mówić wyłącznie po niemiecku" (Nikitorowicz, 2015a, s. 153). Zob. (Dancák, 2016, ss. 33-46).

12 Nikitorowicz przyjmuje, ,że droga do aktywnego uczestnictwa w kulturze europejskiej i planetarnej prowadzi poprzez przeżycie i zrozumienie własnej tożsamości, uświadomienie zasiedzenia lub osadzenia terytorialnego i komunikację z innymi kulturami” (Nikitorowicz, 2011b, s. 7). „Problem komunikacji międzykulturowej nabiera obecnie szczególnego znaczenia [...]. Komunikacja międzykulturowa [...] jest odzwierciedleniem procesów zachodzących w życiu rodziny, szkoły, określonej grupy etnicznej, społeczności lokalnej. W obliczu kryzysu wielokulturowości kształtowanie aktywnych, pozytywnych postaw wobec odmienności jest istotnym zadaniem edukacji” (Szczurek-Boruta, 2013b, s. 156). O komunikacji międzykulturowej zob. (Korporowicz, 2015, ss. 18-35); (Sobecki, 2016); (Jaskuła, Korporowicz, 2013, ss. 121-138).

13 „Negatywne konotacje etnocentryzmu nie powinny przesłaniać istotnej roli w procesie wykształcenia poczucia własnej tożsamości, odniesień do innych grup. To, czy będzie to odniesienie negatywne czy pozytywne, zależy od stopnia wykształcenia poszczególnych czynników tożsamości etnicznej" (Nikitorowicz, 1995, s. 87). 
nietolerancją [...] i dyskryminacją?" (Nikitorowicz, 2003, s. 59). Aby uniknąć negatywnych konsekwencji etnocentryzmu świata zakorzenienia, trzeba uznać, że wpisane w indywidualną i społeczną biografię doświadczenie „uczenia się kultury przez »nasiąkanie« nią, bez jej oceny i wartościowania" (Nikitorowicz, 2003, ss. 59-60) wymaga pedagogicznego - rozważnego i powściągliwego - zaangażowania. Wymagane jest bowiem wsparcie w kształtowaniu umiejętności refleksyjnego dystansowania się do własnego etnocentryzmu świata zakorzenienia, zdolności krytycznego formułowania oceny tego, czym się „nasiąkło”, co się oswoiło i przez co zostało się oswojonym, co jawi się jako aż nadto swojska oczywistość, którą bezdyskusyjnie wszyscy inni powinni podzielać. Na potrzebę rzetelnego uwzględniania złożoności zjawiska zakorzenienia wskazuje Nikitorowicz: „[...] promowanie własnej kultury przez jej wyodrębnienie [...], określenie jej walorów z jednej strony może rodzić niebezpieczeństwo kulturowego zamknięcia się w „skansenie kulturowym" [...], z drugiej zaś jest nieuniknionym i podstawowym krokiem w procesie stawania się tożsamościowego" (Nikitorowicz, 2003, s. 60) ${ }^{14}$. Pedagogicznie i refleksyjnie pogłębiona afirmacja wartości etnocentryzmu świata zakorzenienia wymaga zastrzeżeń, iż wychodząc od przyjętego jako dziedzictwo „etnocentryzmu naturalnego” dąży się - również dzięki teoretycznie dopracowanej edukacji międzykulturowej - do ukształtowania "nowego etnocentryzmu"15. Należy się uczyć niezbędnej w relacjach międzykulturowych

14 Na potrzebę rozeznania i uwzględniania w edukacji dwoistości sytuacji tożsamościowotwórczej Nikitorowicz wielokrotnie zwraca uwagę: „Osadzenie terytorialne z jednej strony może powodować kształtowanie tożsamości zamkniętej - skansenowej, z drugiej zaś sprzyjać kreowaniu tożsamości rozproszonej, wielokulturowej" (Nikitorowicz, 2005, s. 25). Zob. (Szulich-Kałuża, 2016, ss. 25-41).

15 Na przenikające się procesy zaniku i odrodzenia tożsamościowego, przechodzenie od rozkładu do rewitalizacji podmiotowości w dziedziczeniu świata zakorzenienia, wskazuje Nikitorowicz syntetyzując wyniki badań: „W efekcie wieloletnich badań terenowych w regionie północno-wschodniej Polski stwierdziłem z jednej strony postępujący rozkład zasobów kulturowych jednostek i grup mniejszościowych, wydziedziczanie z kultury przodków [...], z drugiej zaś [...] wskaźniki odradzania podmiotowości regionalnej, wyznaniowej, etnicznej, uświadamiania specyfiki odrębności i korzeni kulturowych. [...]. [...] rodzima kultura staje się źródłem siły i poczucia dumy [...]" (Nikitorowicz, 1997, s. 168). O tożsamości regionalnej zob. (Świątkiewicz, 2001, s. 81-89); (Grabowska, 2015, ss. 31-42); (Gumuła, 2016, ss. 27-37). „Tożsamość kulturową można [...] ujmować jako zachowanie ciągłości wartości podstawowych, ich hierarchii, a także podstawowych źródeł i treści systemów legitymizujących całokształt oczywistości społecznego świata" (Świątkiewicz, 1991, s. 14). 
umiejętności unikania „deprecjonowania kultur innych” (Nikitorowicz, 2003, s. 59) ${ }^{16}$, dlatego konieczne jest (m.in. dzięki diagnozie i prewencji pedagogicznej) „przeciwstawianie się agresywnemu etnocentryzmowi, hegemonii własnych wartości, ksenofobii, megalomanii, nacjonalizmowi, dyskryminacji [...]" (Nikitorowicz, 2011b, ss. 9-10). Ale te dążenia muszą mieć drugie oblicze: w nieantagonistycznych relacjach międzykulturowych niezbędna jest „prezentacja i obrona własnego świata zakorzenienia” (Nikitorowicz, 2003, s. 59). Bez tych odniesień do „świata zakorzenienia” - tak spontanicznych, jak i zreflektowanych - wzmagają się patologie destrukcji tożsamościowej ${ }^{17}$, co uniemożliwia kształtowanie relacji międzykulturowych i wykształcanie „międzykulturowej tożsamości”. Podobnie sprawę aksjologicznej i edukacyjnej doniosłości zakorzeniania ujmuje Alina Szczurek-Boruta w badaniach pogranicza: „[...] kształtowanie tożsamości wielowymiarowej wymaga [...] kulturowego zakorzenienia - internalizacji wartości, przekonań [...] [i wzorów] uczestniczenia we wspólnocie (wspólnotach); działań edukacyjnych oraz wsparcia polityki oświatowej” (Szczurek-Boruta, 2017, s. 197).

Jeśli na - uzyskane w połowie lat dziewięćdziesiątych XX wieku - wyniki badań nad przebiegiem nauczania szkolnego na pograniczu północno -wschodnim Polski, a zwłaszcza wyniki badań nad przekonaniami i działaniami nauczycieli, spojrzeć w perspektywie wartości etnocentryzmu świata zakorzenienia, to prowadzą one - tak jak ujmuje to Nikitorowicz - do budzących niepokój konstatacji: „[...] nauczyciel nie posiada programu pracy w społecznościach zróżnicowanych kulturowo. Wartości edukacyjne regionu nie są uwzględniane [...]; nie przygotowuje do rozumienia „inności”, [...] traktując odmienności kulturowe jako przeżytek i wstecznictwo, [...] doprowadzając

16 Uczenie się międzykulturowe - jako zmierzanie ku tożsamości wielowymiarowej i integracji społecznej - zakłada „[...] nieustanne uczenie się w kontaktach międzyludzkich, uwrażliwianie kulturowe w bezpośrednim kontakcie z innością, [a są] to istotne warunki nie tylko do kształtowania się tożsamości ludzi świadomych siebie, swoich możliwości, ale i warunki integracji społecznej [...] do uczenia się międzykulturowego dochodzi podczas bezpośrednich kontaktów z reprezentantami innych, odrębnych kultur, wyznań; także w relacjach z osobami niepełnosprawnymi, osobami żyjącymi na marginesie społecznym czy dotkniętymi biedą. W przeciwieństwie do tradycyjnego uczenia »z zewnątrz«, czy też »z góry«, uczenie międzykulturowe pozwala uczyć »do środka«, czyli od innych i z innymi” (Szczurek-Boruta, 2012, s. 28).

17 Destrukcyjne skutki dezintegracji tożsamościowej (korelacje między różnorodnością kulturową i rozpadem tożsamości) analizuje Krzysztof Wielecki (Wielecki, 2014, ss. 41-52). 
ucznia do kompleksów i wstydu za [...] zachowania kulturowe wyniesione z rodziny pochodzenia" (Nikitorowicz, 1997, s. 172) ${ }^{18}$.

Nie uznając wartości świata zakorzenienia jako zobowiązania do określonych działań pedagogicznych, które mają respektować te wartości, nie dostrzega się też - jak w przypadku badanych nauczycieli - spustoszenia w wymiarze osobowym (duchowym, intelektualnym, autoidentyfikacyjnym). To wyjałowienie dotyka wychowanków poddanych sile przymusu szkolnego, sile działań oświatowych, niezreflektowanych co do zasad edukacji aksjologicznej, regionalnej i międzykulturowej ${ }^{19}$. Perspektywa etnocentryzmu daje natomiast możliwość rozpoznawania wartości związanych z tożsamościowotwórczym procesem zakorzeniania się w tradycji, którego potencje - również dzięki właściwie prowadzonej edukacji - urzeczywistnia się i aktualizuje uwzględniając teraźniejsze wyzwania i prospektywne wizje ${ }^{20}$.

Jeśli w nastawieniu właściwym dla etnocentryzmu świata zakorzenienia dokonuje się rozeznania współczesnej kultury, to pod krytykę podpadają te jej formy, które przemieniają wielowymiarową egzystencję człowieka (dążącego do samostanowienia) w determinowany siłami społecznymi i koniecznościami cywilizacyjnymi los istoty wykorzenionej i zdezorientowanej aksjologicznie. Idąc tym tropem, Nikitorowicz artykułuje krytyczne uwagi: „[W] świecie kultury masowej [...] gubimy to, co najbardziej ludzkie. W przeroście wartości materialno-pragmatycznych nad uniwersalistycznymi, transcen-

18 O kształtowaniu pedagogicznego myślenia i wyobraźni zob. (Śliwerski, 2010). Badania kultury pedagogicznej nauczyciela i jego przygotowania do pracy w warunkach wielokulturowości przedstawia w swych studiach Alina Szczurek-Boruta: (Szczurek-Boruta, 2013a); (Szczurek-Boruta, 2014); (Szczurek-Boruta, 2013b, ss. 155-169).

19 „[...] oddziaływania szkoły [...] miały na celu eliminację tożsamości rodzinnej, [...] odmienności regionalnej, językowej czy etnicznej, co przejawiało się w podważaniu tej tożsamości, języka i wyznania przodków, wyszydzaniu [...] zachowań, [...] karaniu za przejawy inności" (Nikitorowicz,1995, s. 124). O roli nauczyciela i szkoły w relacjach międzykulturowych zob. m.in. (Kojs, 1995, ss. 93-104); (Szczurek-Boruta, 2007a); (Suchodolska, 2010, ss. 167-181); (Ogrodzka-Mazur, 2017b, ss. 61-79); (Rembierz, 2017d, ss. 15-53).

20 „[W] edukacji winno być [...] miejsce na kultywowanie dziedzictwa kulturowego, jako niezbędnego elementu uświadomienia i nabywania tożsamości [...] i kształtowania systemu wartości. Podejmując równolegle działania [...] międzykulturowe stworzymy możliwość budowania na tożsamości zakorzenionej z ojczyzną prywatną i [...] na tej bazie kształtowania tożsamości wielokulturowej, rozproszonej na inne kultury" (Nikitorowicz, 1995, s. 54). O zakorzenieniu i ojczyźnie prywatnej zob. (J. Szczepański, 2003); (M.S. Szczepański, 1996, ss. 167-175). 
dentnymi coraz mniej miejsca pozostaje na odnajdywanie siebie, rozumienie siebie i innych" (Nikitorowicz, 1997, s. 168) ${ }^{21}$. Spostrzeżenia o zagubieniu tego, „co najbardziej ludzkie”, są zbieżne z tymi, które czyni Margaret S. Archer: „[...] model homo oeconomicus'a nie uwzględniał naszej normatywności i emocjonalności, które mają charakter intencjonalny i dotyczą naszej relacji z otoczeniem - naturalnym, praktycznym, społecznym. Nie można było pozwolić by relacje te [...] określały to, kim jesteśmy. [...] zubożonym modelem »człowieka" stał się samotny, wyizolowany i oportunistyczny łowca okazji" (Archer, 2013, s. 8). Wyzbycie człowieka z właściwości, które daje zakorzenienie, prowadzi do redukcji i destrukcji antropologicznej (tożsamościowej), która uniemożliwia kształtowanie relacji międzykulturowych i wykształcanie „międzykulturowej tożsamości”. W świecie społecznym dominuje „model człowieka”, o którym powiada się, że „zna cenę wszystkiego, lecz nie zna wartości niczego" (Archer, 2013, s. 8). Ten uproszczony w zakresie aksjologii „model człowieka” niesie poważne niedostatki w zakresie ludzkich trosk i relacji. Tak pojętemu człowiekowi nowoczesności „brakowało środków, by osiągnąć odrębną tożsamość osobistą, która jest efektem określenia naszych trosk ostatecznych i pogodzenia ich z pozostałymi troskami" (Archer, 2013, s. 8$)^{22}$. Ludzie bez odrębnej tożsamości osobistej nie są zdolni do współkształtowania relacji międzykulturowych i „międzykulturowej tożsamości”, natomiast pojawiają się „tożsamościowe atrapy”, pozbawione zakorzeniania i puste, podatne na przyswajanie patologicznych treści.

Gdy rozpatruje się kwestie ludzkiej potrzeby zakorzenienia, to częstokroć w literaturze przedmiotu, także w dociekaniach Nikitorowicza, przytacza się - traktowany jak manifest w sprawie zakorzenienia - rzec można paradygmatyczny wywód Simone Weil (1909-1943) z jej ostatniego (pisanego na emigracji w czasie II wojny światowej) tekstu L'Enracinement. Prélude à une déclaration des devoirs envers l'être humain:

Zakorzenienie jest być może najważniejszą i równocześnie najbardziej zapoznaną potrzebą duszy ludzkiej, a przy tym jedną z najtrudniejszych do zdefiniowania. Istota ludzka zakorzenia się poprzez rzeczywisty,

21 „[...] istotą edukacji jest uświadomienie wartości i zasad życia społecznego niezwiązanych bezpośrednio z walką o byt, o przetrwanie, a odnoszących się do etyczno-moralnej sfery uczuć. [...] wyzwanie to może podjąć edukacja w rozumieniu starożytnej Grecji, edukacja przygotowująca do bycia dobrymi obywatelami polis, [...] edukacja kreująca nowe przestrzenie rozwoju w dialogu z innymi" (Nikitorowicz, 2014b, s. 19).

22 Archer wykazuje, że „specyficzny sposób porządkowania trosk nadaje ludziom ich unikatową tożsamość osobistą" (Archer, 2013, s. 13). 
czynny i naturalny udział w istnieniu jakiejś wspólnoty, która zachowuje żywe skarby przeszłości i wybiega swymi przeczuciami w przyszłość. Udział naturalny warunkują same przez się miejsce zamieszkania, urodzenie, zawód, otoczenie. Każda istota ludzka potrzebuje licznych korzeni. Całość niemal swego życia moralnego, intelektualnego, duchowego powinna ona otrzymać za pośrednictwem środowisk, do których z natury przynależy.

Przede wszystkim dusza ludzka musi być zakorzeniona w wielu środowiskach naturalnych i dzięki nim musi nawiązywać łączność z wszechświatem.

Przykładem takich naturalnych środowisk może być ojczyzna, albo środowiska wyznaczone wspólnym językiem, kulturą, wspólną przeszłością historyczną czy zawodem lub miejscem zamieszkania.

Zbrodnicze jest to wszystko, czego skutkiem może być oderwanie istoty ludzkiej od jej korzeni lub to, co stanowi przeszkodę w jej zakorzenieniu (Weil, 1961, s. 194).

W tym skondensowanym wywodzie, afirmującym zakorzenienie, wyróżnia się kilka tez: (1) zakorzenienie stanowi akt wartościotwórczy, niezbędny dla ludzkiego rozwoju, a w nowoczesności bywa ono niedoceniane, gdyż w imię konstruktywizmu społecznego (inżynierii społecznej) nie uznaje się tego, co zdaje się czymś naturalnym; (2) sprawia ono szczególne kłopoty przy próbach w pełni adekwatnego opisu; (3) jeśli ma być urzeczywistniane, a nie tylko werbalnie deklarowane lub pozorowane, to wymaga realnego uczestnictwa w relacjach międzyludzkich określających przebieg i kształt życia konkretnej społeczności, która funkcjonuje też jako wspólnota pokoleń przekazujących i podejmujących dziedzictwo tradycji; (4) nie jest tylko retrospektywne, ale w głównej mierze jest zorientowane prospektywnie; (5) ma w sobie coś zdecydowanie naturalnego, coś samorzutnego, bierze się jakby z porządku natury (na co naprowadza sens zaczerpniętej z przyrody organicznej metafory zakorzenienia), a nie jest efektem zaprojektowania przez kogoś - w imię dążeń perfekcjonistycznych - doskonalszej konstrukcji społecznej i doskonalszych działań społecznych; (6) wskazuje na niezbędną wielość i na niejako idące z natury zróżnicowanie: „istota ludzka potrzebuje licznych korzeni” i „dusza ludzka musi być zakorzeniona w wielu środowiskach naturalnych"; (7) trzeba odróżniać akt zakorzenienia od „uwiązania”, które z pomocą środków duchowego przymusu (dających podobny efekt jak łańcuchy) przypisuje do jednego miejsca; wraz z zakorzenieniem współwystępuje transcendowanie, przekraczanie miejsca zakorzenienia, gdyż zakorzenienie tak kształtuje człowieka, 
aby chciał i umiał „nawiązywać łączność z wszechświatem”, aby transcendował przypisanie do lokalnych uwarunkowań; (8) niszczenie zakorzenienia, zasługuje na napiętnowanie jako zbrodnia, a systematyczne (systemowe) niszczenie zakorzenienia - na miano „zbrodni z premedytacją”, gdyż wyniszcza siły duchowe człowieka, niweczy u źródeł człowieczeństwo. Te tropy obecne są też w pedagogicznych poszukiwaniach Nikitorowicza ${ }^{23}$.

\section{Wieloaspektowość otwartości (na) pogranicza i ustawiczne uczenie się pluralizmu}

Pogranicza nie są „gdzieś daleko”, nie sytuują się tylko na jakichś bardzo odległych i wręcz mitycznych kresach, ale ich mniej lub bardziej wyraźna obecność i ich swoiste cechy, ich swoiste dynamiczne układy wartości, wpisują się w różnorakie obszary człowieczej egzystencji, jako czynnik współkształtujący, współstanowiąc też o tożsamościowotwórczym (samo)rozumieniu w zakresie podstawowych „spraw ludzkich”.

Rozpatrując sprawę otwartości (na) pogranicza, Nikitorowicz podąża m.in. tropem idei uniwersalizmu pogranicza, które - nawiązując do koncepcji Michała Bachtina (1895-1975) - rozwija Lech Witkowski: „Kategoria granicy (i postulat życiodajnego pogranicza) wydaje się być fundamentem dla myślenia o człowieku, [...] o wrastaniu w człowieczeństwo i w kulturę. Rola tej kategorii rośnie w humanistyce tym bardziej, im bardziej w gruzy idą granice sztuczne, narzucane przemocą (państwa, ideologii, religii...)" (Witkowski, 2000, s. 18 $)^{24}$. Paląca potrzeba kształtowania intelektualnej otwartości (na) pogranicza występuje nie tylko w refleksji i praktyce pedagogicznej dotyczącej relacji międzykulturowych, ale w całości refleksji humanistycznej, która służy ludzkiemu samookreśleniu się i rozpoznawaniu wartości ${ }^{25}$.

23 Tym tropem podąża też m.in. Jolanta Muszyńska: „[...] zakorzenienie jednostki w określonym miejscu jest swoistym kapitałem społecznym, dzięki któremu wytworzone więzi [...] społeczne, są zarówno dobrem prywatnym, jak i dobrem publicznym" (Muszyńska, 2014, s. 92). Zob. też: (Misiejuk, 2013).

24 Warto przywołać (opublikowany w „Kwartalniku Pedagogicznym”) tekst Lecha Witkowskiego, którego już tytuł wskazuje na wiodące idee: W stronę edukacji (dla) pogranicza (pedagogiczne „Bachtinalia”), (Witkowski, 1990, ss. 47-66). Zob. (Witkowski, 1995, ss. 11-23).

25 „PPogranicze] jako leżący poza centrum obszar zróżnicowań [...], gdzie można porównywać, odkrywać, [...] i prowadzić dialog, staje się naturalnym środowiskiem współczesnego człowieka. Bycie na pograniczach staje się normalnością, umożliwia 
W modelowym ujęciu pożądanego typu pogranicza ukazuje się ono jako dynamiczny „proces i efekt tego procesu w komunikacji między ludźmi, w przejściu od monologu do dialogu kultur, od dominacji [...], uprzedzeń do wzajemnego zrozumienia, negocjacji i dbałości o wspólny spadek kultury pogranicza" (Nikitorowicz, 1995, s. 13). Dokonuje się więc niejako samorodna - w zarodku już funkcjonująca - edukacja międzykulturowa: „Ludzie w efekcie codziennych kontaktów nabywają umiejętność bycia i takim, i takim, mimo cech różniących, przypisujących ich do [...] grupy wyznaniowej czy etnicznej" (Nikitorowicz, 1995, s. 13). Jedną z właściwości „człowieka pogranicza”, kształtowaną w relacjach międzykulturowych, jest swoista „umiejętność bycia i takim, i takim”. Unika się dzięki niej destrukcji „rozdwojonej jaźni” i potęgowania sprzeczności (iż „nie wie się, kim się jest” lub koniunkturalnie czy pod przymusem dostosowuje się do dominującej siły). Ta umiejętność pozwala sprawnie poruszać się w występującej w wielu sytuacjach dwoistości i „wieloistości”. Codzienność różnorakich relacji międzykulturowych i wymóg kształtowania międzykulturowej tożsamości w dynamice pogranicza pozwalają - bez zagubienia siebie - ukształtować w sobie takie umiejętności, aby być zarazem „i takim, i takim”; dzięki warunkom pogranicza - jako ustawicznemu wyzwaniu - pojawia się szansa, aby ustawicznie wzmacniać własną, tożsamościową odrębność ${ }^{26}$.

Eksponując tożsamościowotwórcze walory pogranicza, uważając, że wytwarzające się tam sytuacje i relacje sprzyjają formowaniu się i wzmacnianiu podmiotowości i sprawczości, Nikitorowicz wyraża też przekonanie, że dzięki warunkom właściwym dla pogranicza tym bardziej możliwe jest „kształtowanie jednostki rozwijającej się i samosterującej w oparciu o tradycje i dziedzictwo kulturowe”, ale zarazem - jako „człowiek pogranicza”, niosący pamięć o historycznej złożoności doświadczeń pogranicza - dodaje trafne spostrzeżenia o dwoistości sytuacji pogranicza, które chronią przed naiwną apoteozą „utopii pogranicza”: „Z jednej strony [pogranicze] wyzwala poczucie tożsamości społecznej i kulturowej (rodzinnej, religijnej, [...], etnicznej), z drugiej zaś powoduje zagrożenie, utratę poczucia bezpieczeństwa, lęk przed nietolerancją grupy dominującej” (Nikitorowicz, 1995, s. 19). Nie można po-

zrozumienie siebie, własnych i innych poglądów, [...] pozwala uświadomić znaczenie inności w rozwoju [...] siebie. Tylko bycie na pograniczu [...] [uczy] współistnienia, współpracy, życzliwości, otwartości, [...]" (Nikitorowicz, 2014a, s. 178). Zob. (Ogrodzka-Mazur, 2012, ss. 33-41).

26 „Życie na skrzyżowaniu kultur pozwala wykraczać myślowo poza obszar uwarunkowany osiadłością, gdyż [...] uruchamia skale porównawcze, które działają jako bodźce" (Nikitorowicz, 1995, s. 14). 
mijać tej drugiej, trudnej strony sytuacji napięć na pograniczu, kosztów w postaci zagrożeń i lęków, niejako obciążenia pogranicza hipotecznym długiem, będącym kłopotliwą i obciążającą częścią spadku pokoleń, z którego trzeba się wciąż na nowo uwalniać, nie mając jednak pewności, iż w pełni się to powiedzie, bo także w nowej postaci odradzają dawne niepokoje pogranicza.

Sytuacja polifonicznego pogranicza jest sytuacją uczenia się pluralizmu: „Pluralizm musi rozpoznawać w sposób poważny tożsamości i prawa grup i musi reprezentować zbiorową tożsamość. Uwydatniając przynależność do danej grupy jako podstawę uczestnictwa w społeczeństwie, winien zapewniać, że pedagogia, program i metody nauczania, są zgodne z cenionymi różnicami kulturowymi" (Nikitorowicz, 1995, s. 112) ${ }^{27}$. Uczenie się pluralizmu wymaga przezwyciężania dwóch skrajności prowadzących do unicestwiania wartościotwórczych różnic: z jednej strony ujednolicającej uniformizacji, a z drugiej strony jedynie deklaratywnego (werbalnego) promowania wszelakich różnic, które w praktyce sprowadza się do nieliczenia się z dziedziczonymi wraz z tradycją „cenionymi różnicami kulturowym”, na których walory konsekwentnie wskazuje Nikitorowicz.

\section{Odczytanie polskich tradycji pogranicza kultur w edukacji międzykulturowej}

Z punktu widzenia zasad edukacji międzykulturowej Nikitorowicz wysuwa postulat odczytania polskich tradycji pogranicza w kontekście współczesnych wyzwań kulturowych. Przyjmuje za obowiązującą zasadę: „Każda kultura narodowa winna być otwarta na kontakt z inną kulturą, gdyż tylko interakcje międzykulturowe pozwalają na pełne zrozumienie własnej kultury, [...] umożliwiając tym samym jej rozwój [...]" (Nikitorowicz, 2011a, s. 13).

W perspektywie dążeń edukacji międzykulturowej krytycznego rozeznania wymagają te „edukacje narodowe”, które zmierzają do zacieśniania więzi narodowej i są używane "jako instrument władzy politycznej” (Nikitorowicz, 2015a, s. 147). Niepokoją działania edukacyjne i indoktrynacyjne, które afirmując wspólnoty narodowej, „odgraniczają od innych”, aby w ten sposób wzmacniać integrację narodową, i sięgają do „mitotwórczej apologetyki”, propagują

27 O rozumieniu pluralizmu w życiu społecznym i religijnym zob. (Mariański, 1993); (Mariański, 2016, ss. 119-155); (Valčo, 2018, ss. 173-190); (Różańska, 2015); (Rembierz 2017a, ss. 191-237); o rozumieniu pluralizmu w polskiej myśli pedagogicznej zob. (Śliwerski, 2013, ss. 57-84); (Rembierz, 2017b, ss. 105-153). 
mity „wspólnego pochodzenia” i mity o „przewadze duchowej i [...] etycznej w stosunku do sąsiednich narodów, religii” (Nikitorowicz, 2015a, s. 147) ${ }^{28}$. W nastawianiu nacjonalistycznym za zasadę tożsamościowotwórczą przyjmuje się bowiem konfrontowanie wyostrzonych różnic narodowych, zamiast sięgać do aksjologicznych (wartościotwórczych) i edukacyjnych walorów pogranicza jako spotkania i wymiany wartości „etnosów”. W narodowo zideologizowanej edukacji apoteozuje się dzielące granice jako „kordony sanitarne”. Społeczności (narodowe, religijne) spoza granic ukazuje się jako nieustannie potencjalnych wrogów, co ma potwierdzać odczytywanie dziejów jako ciągłych konfliktów i w różnej formie (konfrontacji militarnej, gospodarczej) toczących się wyniszczających walk (włącznie z walką o duszę narodu). Z narodowocentrycznego punktu widzenia wobec edukacji międzykulturowej może paść zarzut, że jest ona (podstępną) formą zdrady narodowych interesów. Dlatego w dojrzałej teoretycznie i efektywnej praktycznie edukacji międzykulturowej przedmiotem refleksji pedagogicznej musi być - jako „paląca” i „zapalna” - kwestia aksjologicznie pogłębionego rozumienia spraw (wartości i idei) narodowych ${ }^{29}$. „Najeżonej” trudnościami interpretacyjnymi i uwikłanej w konteksty walk ideologiczno-politycznych (instrumentalizowanej na użytek walk i rozniecanej przez siły zewnętrzne) problematyki wartości i idei narodowych nie należy marginalizować w edukacji międzykulturowej, nie można usunąć jej poza sferę zainteresowań i propozycji pozytywnych rozstrzygnięć, nie można pozostawić jej wyłącznie we władaniu grup i ideologii (bywa, że skrajnych), które chcą ją zawłaszczyć jako tylko swój temat i swój oręż $\dot{z}^{30}$.

28 Nikitorowicz dostrzega w wielu krajach oddziaływania niedopracowanej aksjologicznie „edukacji narodowej”, krytycznie ocenia ich obecność w polskiej szkole: „Nie uczymy empatii i zaufania, budujemy postawy niechętne wobec innych [...]" (Nikitorowicz, 2015a, ss. 149). Zob. (Przybysz, 2007, ss. 79-98).

29 O patriotyzmie w kontekście edukacji międzykulturowej zob. (Nikitorowicz, 2013b, ss. 29-49); (Gajda, 2013, ss. 50-64); (Ogrodzka-Mazur, 2013, ss. 106-127); (Ostrowska 2019, ss. 33-56); (Kostyło 2019, ss. 57-74).

30 Edukacja międzykulturowa ma ukazywać „historię wielowiekowej tolerancji Rzeczypospolitej wielu narodów. Wielowiekowe funkcjonowanie pogranicza przejściowego, splot wartości kultury Zachodu z dziedzictwem Wschodu był i jest szczególnym bogactwem. Kultura polska wiele zawdzięcza temu [...] pograniczu, gdzie przez wieki czerpano ze spuścizny łacińskiej i bizantyjskiej w otoczeniu i współpracy z żydami oraz muzułmanami, którzy obok budowali swoje świątynie i modlili się w nich. Przez wieki Polacy modlili się po łacinie do ruskiej ikony [...]" (Nikitorowicz, 2016, ss. 60-61). O jagiellońskich inspiracjach dialogu międzykulturowego zob. (Wierzbicki, 2008, ss. 222-230); (Korporowicz, 2016, ss. 23-36); (Rembierz, 2017c, ss. 345-377). 


\section{Tożsamość międzykulturowa jako refleksyjna i twórcza aktywność podmiotu}

Wychodząc od kulturowego doświadczenia wielokierunkowej dynamiki pogranicza i relacji międzykulturowych, a zarazem afirmując kulturowe doświadczenie zakorzenienia, Nikitorowicz wypracowuje - procesualne i akcentujące podmiotową sprawczość - rozumienie tożsamości, którą stanowi przede wszystkim „twórczy wysiłek podmiotu łagodzący napięcia i sprzeczności pomiędzy elementami stałymi, odziedziczonymi, wynikającymi z zakotwiczenia społecznego w rodzinie i społeczności lokalnej, identyfikacji z osobami i grupami znaczącymi, symbolami i wartościami rdzennymi, a elementami zmiennymi, nabywanymi, wynikającymi z interakcji i doświadczeń uczestnictwa w kulturze i strukturach społecznych, przyswajanych i uznawanych norm, wartości i zachowań" (Nikitorowicz, 2005, s. 20; 2006, s. 311). Taką wizję tożsamości, jako bliską sobie wartość intelektualną, Nikitorowicz promuje w tytułach rozpraw: „Tożsamość jako twórczy wysiłek podmiotu otwierający na dialog międzykulturowy" (2006). Jeśli wysiłek jest twórczy, to dąży się do wytworzenia czegoś nowego (nowych stanów rzeczy), czegoś, czego nie było, a tożsamość nie jest zasklepiona w sobie, ale staje się otwarta, otwiera się na to, co nowe, otwiera się na dialog będący formą aktywności twórczej i zmierzający w stronę poznania tego, co nieznane. Nikitorowicz jest przekonany, że wypracowywane „[...] rozumienie tożsamości otwiera na dialog kultur, w którym wzajemne uczestnictwo w procesie otwierania się na siebie i innych jest źródłem siły i poczucia dumy z przynależności do określonej grupy" (2006, s. 312). Ta propozycja tożsamości nie ogranicza się do prezentacji w debacie akademickiej, ale zakłada się, że powinna sprzyjać pozytywnym - wedle kryteriów wartościowania właściwego pedagogice międzykulturowej - zmianom w sytuacjach pogranicza i intensyfikujących się relacjach międzykulturowych w pluralizującym się świecie, powinna służyć kształtowaniu „międzykulturowej tożsamości” ${ }^{\text {31. }}$

31 „Kreowaną zintegrowaną tożsamość można [...] nazwać tożsamością międzykulturową, fenomenem rozwijającym się [...], otwartym [...], wielowymiarowym, łączącym elementy osobowego systemu jednostki z centralnymi wartościami kultury grupy, do której [...] należy, oraz świadomym uczestnictwem w wartościach innych grup, a także wartościach ponadczasowych kultury [...]" (Nikitorowicz, 2003, s. 62). „Uważam, że bez trwałego rdzenia tożsamościowego, jakim jest język domowy, bez wyraźnego samookreślenia na tej bazie własnej odrębności, powstają trudności w kre- 
W stosunku do dawnego pogranicza, silniej od innych sfer naznaczonego tradycyjnym zróżnicowaniem kulturowym, współcześnie - zwłaszcza $\mathrm{w}$ nowych sytuacjach pogranicza - z impetem dokonują się procesy przyśpieszonych przemian i zradykalizowanej pluralizacji, przy czym dotyczą one też tych sfer życia, które dotychczas były względnie stabilne, co sprawia szczególnie dolegliwe kłopoty egzystencjalne i zawirowania aksjologiczne: „Skazani i często zdezorientowani wobec silnej presji kilku równocześnie dokonujących się procesów (m.in. modernizacji, globalizacji, transformacji, integracji), znaleźliśmy się $\mathrm{w}$ wirze nieustannych, dynamicznych, nieprzewidywalnych zmian" (Nikitorowicz, 2006, s. 310). W opisanej tak sytuacji, gdy zawodzą tradycyjne wzorce postępowania (które dotychczas przynosiły zazwyczaj pożądany skutek) i nie są stosowne w nowej sytuacji przejęte w spadku (nabyte przez naśladowanie poprzednich pokoleń) odruchy reagowania, tym bardziej trzeba wypracować w sobie umiejętność trafnego rozeznawania wyzwań nowych rodzajów pogranicza i współczesnej pluralizacji, z którymi trzeba się mierzyć.

Sprawa refleksyjności „człowieka pogranicza”, który kształtuje swą „międzykulturową tożsamość”, ukierunkowuje na kwestię „imperatywu refleksyjnego" mającego ze względu na wymogi przemian społecznych obowiązywać współczesnego człowieka. Kwestię tę uznaje za pierwszoplanową Margaret S. Archer w „The Reflexive Imperative in Late Modernity” (Cambridge 2012). Omawiając teoretyczną i praktyczną doniosłość imperatywu refleksyjnego, Krzysztof Wielecki formułuje uwagi istotne dla kształtowania „międzykulturowej tożsamości":

Żyjemy zatem w czasach „imperatywu refleksyjnego”, wielości nowych, nieznanych wcześniej sytuacji, w których tylko na drodze refleksyjności można pogodzić własne troski z kontekstem społecznym. „Przesocjalizowane" koncepcje człowieka, który miałby być całkowicie uformowany przez socjalizację i charakteryzować się jedynie zdolnościami przystosowawczymi, [...] zupełnie nie odpowiadają rzeczywistości (Wielecki, 2019, s. 36) ${ }^{32}$.

owaniu tożsamości międzykulturowej" (Nikitorowicz, 2012, s.73). Zob. też: (Szczurek-Boruta, 2011, ss. 141-165); (Ogrodzka-Mazur, Klajmon-Lech, Różańska, 2014).

32 O „przesocjalizowanych” koncepcjach człowieka zob. (Rembierz, 2018b, ss. 59-90). Nikitorowicz eksponuje dwoistość działań pedagogicznych, aby nie poprzestać na „przesocjalizowanych” ideach i praktykach: „Należy zauważyć w działaniach edukacyjnych dwie główne funkcje: socjalizacyjną i enkulturacyjną oraz wyzwalającą z socjalizacji i enkulturacji. Jeżeli pierwsza uspołecznia oraz ukulturalnia i czyni [...] 


\section{Od agnozji do gnozeologii międzykulturowej - o potrzebie (wzajemnego) poznania}

Terminem agnozja (nieświadomość, nieznajomość) określa się zaburzenie zdolności rozpoznania dotychczas znanych elementów otoczenia. Swoista agnozja bywa doświadczana, gdy uprzednio znana i uchodząca za oczywistą postać naszego świata jest ukazywana w dalece odmienny sposób i przeniesiona w inny układ odniesienia, jest opisywana z wykorzystaniem takich kategorii pojęciowych, których sens trudno nam zrozumieć, bo mówi o niej ktoś spoza naszego świata, ktoś inaczej postrzegający, rozumiejący i wartościujący "całość" świata i jego elementy. Jeśli zawiesza się własne (dotychczas nabyte) nastawienie poznawcze i próbuje się „po omacku” podążać za radykalnie innym widzeniem rzeczywistości (wręcz innym sposobem bycia), to niknie to, co było dobrze znane, a z wolna zaczyna się ukazywać coś innego. Od tego doświadczenia agnozji, aby na nim nie poprzestać (np. jako na ekscytującym eksperymencie), trzeba - ze względu na wymogi edukacji międzykulturowej - przejść do wypracowania elementów gnozeologii międzykulturowej, elementów teorii wiedzy (teorii poznania) odpowiednich do tego, co się dokonuje w relacjach międzykulturowych ${ }^{33}$.

W punkcie wyjścia kształtowania relacji międzykulturowych sytuuje się - jako czynność i jako wytwór - rzetelne poznanie różnych wymiarów tych relacji i zarazem jest to poznanie właściwe (swoiste) dla tych relacji. Idąc

członkiem społeczności [...], to druga sprowadza się do wyzwalania spod dominacji społecznej i możliwego zawłaszczenia kulturowego, [...] do wyzwalania działań twórczych [...], rozwijania własnego sprawstwa, poszukiwania nowych jakości [...], do świadomego funkcjonowania na pograniczach kultur. To powoduje rozszerzanie potencjału [...] możliwości edukacyjnych, kształtuje świadomość potrzeby uwolnienia się od istniejących podziałów, od reagowania [...] lękiem, uprzedzeniem [...]" (Nikitorowicz, 2019, s. 11). „[Jeżeli przyjąć], że człowiek nie ma swoistej natury, a jest wytworem środowiska społecznego [...], to wszystko jest możliwe. »Natura (jednostki) jest wyłącznie bezkształtnym tworzywem, które czynnik społeczny formuje i przekształca« (Durkheim). Edukacja [...] [staje się] instrument[em] władzy politycznej, [...] ma miejsce przemoc symboliczna [...]. [Narzuca się] jednorodną perspektywę myślową [...] grupy dominującej innym grupom" (Nikitorowicz, 2017b, s. 14).

33 Zob. (Szczurek-Boruta, A. 2007b); (Klajmon-Lech, Lewowicki, Różańska, red. 2016); (Rembierz, 2017e, ss. 37-67). 
tropem klasycznej tezy o pierwszeństwie poznania, na którym powinno się „oprzeć" sprawne działania, Nikitorowicz w dociekaniach fundujących pedagogikę międzykulturową wyraża epistemologicznie (gnozeologicznie) ukierunkowane przeświadczenie: „Głównym problemem związanym z wielokulturowością jest wzajemne poznanie się w kontekście postrzegania siebie. [...] winny nas interesować różne skutki [...] wzajemnego postrzegania się" (Nikitorowicz, 2011a, s. 24). Poznania innych w relacjach międzykulturowych nie dokonuje zdystansowany i odseparowany od innych podmiot, ale poznaje uczestnik tych relacji i poznaje wespół z innymi uczestnikami. Poznanie dotyczy też aktów i wytworów wzajemnego poznawania się, pełni więc rolę krytycznego metapoznania.

Poznanie, dzięki któremu zyskuje się wartościową - ze względów na walory poznawcze - wiedzę o relacjach międzykulturowych i wiedzą przydatną w tych relacjach, to poznanie jest formą zaangażowanego uczestnictwa w nich i wydatnie je współkształtuje. Nie jest poznaniem bezzałożeniowym i nie jest prowadzone z „boskiego punktu widzenia”. Pozostaje ono osadzone (zakorzenione) we własnych kulturowych i aksjologicznych doświadczeniach poznającego podmiotu (poznających podmiotów) i do tych doświadczeń w istotny sposób się odwołuje: „Pierwsze identyfikacje z grupą i jej wartościami stają się punktem odniesienia w wysiłkach poznania i zrozumienia świata i nigdy nie mogą się od tego świata zakorzenienia oderwać" (Nikitorowicz, 2003, ss. 59-60) ${ }^{34}$. Co więcej, przyjmuje się, że wskazane tu uwarunkowania kulturowe i inicjacje aksjologiczne, które dokonują się w wyróżnionym obszarze „oswojonego świata zakorzenienia”, powinno się w procesie poznania należycie uwzględniać (natomiast poważnym błędem w postępowaniu wiedzotwórczym jest ich pomniejszanie lub pomijanie). Są one bowiem jak najbardziej pożądane w aktywności poznawczej, gdyż za słuszne uchodzi domniemanie, wedle którego „im mniej mamy wiedzy o swojej kulturze, tym niechętniej poznajemy inne kultury i częściej reagujemy na nie lękowo, traktując je jako zagrażające” (Nikitorowicz, 2003, s. 59). Pomnażaniu wartościowego poznania dotyczącego Innych współuczestników relacji międzykulturowych powinno więc towarzyszyć - jako równoległe -pomnażanie wartościowego poznania własnej tradycji kulturowej i jej dziedzictwa. Również

34 „Trzeba cenić i wspierać inicjatywy nadające wartość tożsamości dziedziczonej, jednocześnie wchodząc w interakcje z innymi kulturami, [...] przełamując izolacjonizm i etnocentryzm, co jest pierwszym i koniecznym etapem zrozumienia siebie i swojej kultury" (Nikitorowicz, 2003, s. 53). 
w poznaniu dającym wiedzę o relacjach międzykulturowych ma się spełniać zasada właściwa dla sytuacji pogranicza i człowieka pogranicza, wyrażana przez „zarazem”, „równocześnie”, „z różnych stron”. Poznanie w relacjach międzykulturowych nie powinno być tylko jednostronne, odseparowane w imię osiągania prostoty i jednoznaczności od złożoności i wieloznaczności, zredukowane tylko do idealizacyjnych i przejrzystych ujęć, w których pomija się wielość i nieprzenikliwość różnych czynników. To poznanie, jeśli ma być w odniesieniu do relacji międzykulturowych rzetelne, to znaczny też realistyczne, a nie uciekać w projekcję wyobrażeń i konstruktów, nastręcza szczególne kłopoty m.in. co do wartościowania jego przebiegu (metod postępowania) i jego wyników. Niepokojąca niepewność i szczypta sceptycyzmu, postawa „niekonsekwencji względem niekonsekwencji”, musi towarzyszyć dążeniom poznawczym, acz bez popadania w paraliżujące lub delegitymizujące te dążenia formy radykalnego sceptycyzmu (nihilizmu) co do możliwości poznawczych i uznania, że tylko eksperymentująca praktyka (mimo jej kosztów i strat) pozwoli zrealizować zamierzone modele i wzorce stanu pożądanego.

\section{W stronę heterologii jako nauki i wiedzy o Innym}

Zmierzając do ogólniejszych ujęć teoretycznych problematyki Innego, pogranicza i relacji międzykulturowych, ujęć dopełniających pedagogikę międzykulturową, Nikitorowicz przeprowadza rewitalizację heterologii, wykazując jej potrzebę w sytuacjach zróżnicowania kulturowego. Za zadanie pedagogiki międzykulturowej uznaje wypracowanie heterologii, która „zakłada uczestnictwo w kulturze własnej oraz poznawanie i uczestniczenie w życiu innych kultur, prowadzenie [...] dialogu międzykulturowego" (Nikitorowicz, 2019, s. 11$)^{35}$.

Heterologia odwołuje się do takiej koncepcji człowieka, która docenia doświadczenie „człowieka pogranicza”, w założeniach rewitalizacji heterologii podkreśla się, iż chodzi o to, aby - w wymiarach teoretycznym i edukacyjnym - „dostrzegać wielość kultur w jednym człowieku i uczyć o niej”, aby odkrywać jego „przynależność do wielu kultur jednocześnie” (Nikitorowicz, 2017a, s. 221) i zmierzać do „dialogowego paradygmatu współistnienia” (Nikitorowicz,

35 Rozwijanie heterologii Nikitorowicz wiąże m.in. z pytaniami: „[...] jak edukować dzieci, młodzież, dorosłych, aby trwać jako naród i państwo, ze swoistymi wartościami i równocześnie uczestniczyć aktywnie w procesie dialogu z innymi narodami [...], nie znikając kulturowo w globalnym świecie?” (Nikitorowicz, 2019, s. 11). 
2019, s. 9) ${ }^{36}$. Pedagogika międzykulturowa, rozwijając badania, ma współdziałać z heterologią, powinna „promować heterologię jako ideę, zasadę i postawę, przedstawiając [...] poglądy wielu filozofów i pedagogów dialogu, kształtować postawy i umiejętności prowadzenia dialogu [...]" (Nikitorowicz, 2019, s. 11). Otwarcie pedagogiki międzykulturowej na heterologię wraz z zespolonymi z nią wartościami jest wyrazem przyswojenia dialogiki, której elementy czerpie się z filozofii dialogu i spotkania ${ }^{37}$. W zamyśle Nikitorowicza ujawnia się projekt skorelowania badań. Pedagogika międzykulturowa - dzięki jej wiedzy o walorach pogranicza i relacji między kulturami - ma uczestniczyć, jako inicjatorka i siła wiodąca, w kształtowaniu interdyscyplinarności badań. Ma dostarczać argumentów, że należy przekraczać dziedziczone przez dyscypliny ich historyczne granice, dzielące na różne tradycje intelektualne (niby nieprzystające do siebie). Pedagogika międzykulturowa ma oddziaływać na arbitralnie rozdzielone, a przecież pokrewne dyscypliny, ukazując ich - łączące je - pogranicza i integrując je wokół wspólnej problematyki. Takie dopełnianie się badań i wyjście na intelektualne pogranicza powinno pomóc w dynamizacji rozwoju pedagogiki międzykulturowej, a także w unikaniu pułapek homogeniczności; umożliwia bowiem spojrzenie z krytycznym dystansem i ze szczyptą sceptycyzmu z perspektywy innych punktów widzenia na własne zapatrywania, które wymagają korygowania $^{38}$. Dzięki takiemu postępowaniu - zasadnemu metodologicznie i usprawiedliwionemu aksjologicznie - pedagogika międzykulturowa będzie mogła efektywniej sprostać wyzwaniom badawczym, które niesie z sobą złożoność relacji międzykulturowych.

36 Nikitorowicz postuluje rozwój heterologii „w celu uczenia o wielości kultur otaczających człowieka i bogactwa kultur w jednym człowieku, przynależności do wielu kultur jednocześnie" (Nikitorowicz, 2017b, s. 17).

37 „Iddea] dialogu jest zawarta [...] w edukacji, [...] [a] istotę dialogu międzykulturowego stanowi dostrzeganie odmienności i wyłączności człowieka poprzez poznawanie jego osoby [...]. Dialog taki opierałby się na ontologii „pomiędzy”, [...] zakładając twórczy wysiłek i umiejętność wyjścia uczestników [...] na pogranicza kulturowe” (Nikitorowicz, 2013a, s.18). O pedagogicznych i międzykulturowych aspektach dialogu (Gara, 2008); (Milerski, 2008, ss. 29-42); (Kabzińska, 2008, ss. 21-41); (Szulakiewicz, 2010, ss. 34-53); (Wieczorek, 2017, ss. 76-103), (Czajka, 2016); (Cudowska, 2011, ss. 69-83); (Dojčár, 2018, ss. 40-49); (Dancák, 2019, ss. 73-83).

38 „Sądzę, że byliśmy pilnymi uczniami, zapraszaliśmy [...] socjologów, psychologów, politologów, historyków, etnologów, filozofów, filologów. [...] staraliśmy się wspólnie i samodzielnie odrabiać lekcje rozumienia siebie i innych w warunkach wielokulturowości [...]” (Nikitorowicz, 2011b, s. 10). 


\section{Bibliografia}

Archer, M.S. 2012. The Reflexive Imperative in Late Modernity. Cambridge: Cambridge University Press.

Archer, M.S. 2013. Człowieczeństwo. Problem sprawstwa. Kraków: Zakład Wydawniczy Nomos.

Cudowska, A. 2011. Dialog w edukacji międzykulturowej - kształtowanie przestrzeni spotkania z Innym. Pogranicze. Studia Społeczne. XVII, ss. 69-83.

Czajka, A. 2016. Międzykulturowość i filozofia. Warszawa: UKSW.

Dancák, P. 2016. O symptómoch nábožensky motivovanej xenofóbie v medziach tolerancie a nejasného pluralizmu. W: Dojčár, M. red. Religiofóbia: realita, prevencia a edukácia. Trnava: Trnavská univerzita, ss. 33-46.

Dancák, P. 2019. Dialogue and solidarity as a basis for addressing the current migration crisis. Acta Missiologica. 2, ss. 73-83.

Dojčár, M. 2018. Dialogue as a Form of Proclamation. Acta Missiologica. 2, ss. 40-49.

Gajda, J. 2013, Racjonalny patriotyzm jako antidotum skrajnego nacjonalizmu. W: Nikitorowicz, J. red. Patriotyzm i nacjonalizm: Ku jakiej tożsamości kulturowej? Kraków: Oficyna Wydawnicza „Impuls, ss. 50-64.

Gara, J. 2008. Pedagogiczne implikacje filozofii dialogu. Kraków: WAM.

Grzybowski, P.P. 2007. Edukacja europejska - od wielokulturowości ku międzykulturowości. Kraków: Oficyna Wydawnicza „Impuls”.

Grabowska, B. 2015. Rewitalizacja tożsamości regionalnej. Chowanna. 44 (1), ss. 31-42.

Gumuła, W. 2016. Moja Opolszczyzna: o klimacie regionalnym na Śląsku Opolskim. W: Sawicka, V. i Pasierbiński, A. red. Śląsk jest jakiś inny... Opole: Instytut Śląski, ss. 27-37.

Jasiński, Z. 2009. Recz o możliwych polach konfliktów w środowiskach zróżnicowanych etnicznie i zadaniach edukacji międzykulturowej. W: Lewowicki, T., Ogrodzka-Mazur, E. i Urban, J. red. Społeczne uwarunkowania edukacji międzykulturowej. Cieszyn - Warszawa - Toruń: Wydawnictwo Adam Marszałek, ss. 139-151.

Jaskóła, S. i Korporowicz, L. 2013. Międzykulturowa kompetencja komunikacyjna jako transgresja. Pogranicze. Studia Społeczne. XXI, ss. 121-138.

Kabzińska, I. 2008. Spotkanie z innym w dialogu międzykulturowym. Etnografia Polska. 1-2, (L II), ss. 21-41.

Klajmon-Lech, U., Lewowicki, T. i Różańska, A. red. 2016. Z teorii i praktyki badań międzykulturowych. Dylematy metodologiczne. Cieszyn - Torun: UŚ, Wydawnictwo Adam Marszałek. 
Kojs, W. 1995. Młodzi nauczyciele Pogranicza - co sobie cenią? Czego oczekują? Do czego dążą? Co chcą zmienić? W: Lewowicki, T. red. Społeczności młodzieżowe na pograniczu. Cieszyn: Uniwersytet Śląski - Filia w Cieszynie, ss. 93-104.

Kołakowski, L. 1989. Pochwała niekonsekwencji. W: Kołakowski, L. Pochwata niekonsekwencji. Pisma rozproszone z lat 1955-1968, wybór i oprac. Z. Mentzel. Tom II. Londyn: Puls, ss. 154-160.

Kołakowski, L. 1990. Horror metaphysicus. Warszawa: Res Publica.

Kołakowski, L. 2004. O tym, co jest ważne w życiu. Rozmowa J. Żakowskiego https://www.polityka.pl/tygodnikpolityka/spoleczenstwo/11583,1,profleszek-kolakowski-o-tym-co-jest-wazne-w-zyciu.read (8 grudnia 2017).

Korporowicz, L. 1997. Wielokulturowość a międzykulturowość: od reakcji do interakcji. W: Kempny, M., Kapciak, A. i Łodziński, S. red. U progu wielokulturowości. Nowe oblicza społeczeństwa polskiego. Warszawa: Oficyna Naukowa, ss. 64-72.

Korporowicz, L. 2016, Jagiellońskie inspiracje dialogu międzykulturowego. W: Korporowicz, L. i Plichta, L. red. Mosty nadziei. Jagiellońskie inspiracje dialogu międzykulturowego. Kraków: Biblioteka Jagiellońska, ss. 23-36.

Kostkiewicz, J. 2017. Temporalna zmienność życia wartościowego a uniwersalizm wartości w świetle filozofii i pedagogiki realistycznej. Polska Myśl Pedagogiczna. 3, ss. 31-44.

Kostyło, P. 2019, Edukacja patriotyczna w szkołach publicznych. Filozofia Edukacji. 1, ss. 57-74.

Lewowicki, T. 2000. W poszukiwaniu modelu edukacji międzykulturowej. W: Lewowicki, T., Ogrodzka-Mazur, E. i Szczurek-Boruta, A. red. Edukacja międzykulturowa w Polsce i na świecie. Katowice: UŚ, ss. 21-35.

Lewowicki, T. 2013, Edukacja wobec odwiecznych i współczesnych problemów świata - konteksty i wyzwania edukacji międzykulturowej. Edukacja Międzykulturowa. 2, ss. 19-37.

Lewowicki, T. 2017. Edukacja międzykulturowa - kilka lat później. Zmiana uwarunkowań, pytania o kondycję, wyzwania. Edukacja Międzykulturowa. 2 (7), ss. 19-36.

Mariański, J. 1993. Religia i Kościót w spoteczeństwie pluralistycznym. Polska lat dziewięćdziesiątych. Lublin: RW KUL.

Mariański, J. 2016. Megatrendy religijne w społeczeństwach ponowoczesnych. Studium socjologiczne. Torun: Wydawnictwo Adam Marszałek.

Mariański, J. 2019. Socjologia i moralność. Czym jest i dokad zmierza socjologia moralności. Toruń: Wydawnictwo Adam Marszałek. 
Milerski, B. 2008. Pedagogika dialogu: filozoficzne inspiracje i perspektywy. Paedagogia Christiana. 21 (1), ss. 29-42.

Misiejuk, D. 2013. Dziedzictwo i dziedziczenie w kontekście procesów socjalizacji. Studium teoretyczno-empiryczne o procesach dziedziczenia kulturowego na historycznym pograniczu Podlasia. Białystok: Wydawnictwo Uniwersyteckie „Trans Humana”.

Mucha, J. 1992. Konflikt, symbioza, izolacja. Stosunki etniczne na polskim Podkarpaciu. Etnografia Polska. XXXVI, z.1, ss. 65-78.

Muszyńska, J. 2014. Miejsce i wspólnota. Poczucie wspólnotowości mieszkańców pótnocno-wschodniego pogranicza Polski. Studium pedagogiczne. Warszawa: ŻAK.

Nikitorowicz, J. 1995. Pogranicze, tożsamość, edukacja międzykulturowa. Białystok: Wydawnictwo Uniwersyteckie „Trans Humana”.

Nikitorowicz, J. 1997. Tożsamość a akomodacja. Studia Etnologiczne i Antropologiczne. 1, ss. 168-175.

Nikitorowicz, J. 2000a. Młodzież pogranicza kulturowego Białorusi, Polski i Ukrainy wobec integracji europejskiej. Tożsamość, plany życiowe, wartości. Białystok: Wydawnictwo Uniwersyteckie „Trans Humana”.

Nikitorowicz, J. 2000b. Socjotechnika w edukacji regionalnej i międzykulturowej wobec celów i wartości młodzieży oraz idei zjednoczonej Europy. W: Lewowicki, T., Ogrodzka-Mazur, E. i Szczurek-Boruta, A. red. Edukacja międzykulturowa w Polsce i na świecie. Katowice: UŚ, ss. 37-53.

Nikitorowicz, J. 2003. Typy tożsamości człowieka w społeczeństwie zróżnicowanym kulturowo. Chowanna. 1, ss. 50-66.

Nikitorowicz, J. 2005. Kreowanie tożsamości dziecka w społeczeństwie zróżnicowanym kulturowo. W: Izdebska, J. i Sosnowski, T. red. Dziecko i media elektroniczne - nowy wymiar dzieciństwa. T. 1. Telewizja i inne mass media w życiu dziecka - wyzwaniem dla edukacji medialnej. Białystok: Wydawnictwo Uniwersyteckie „Trans Humana”, ss. 15-26.

Nikitorowicz, J. 2006. Tożsamość jako twórczy wysiłek podmiotu otwierający na dialog międzykulturowy. W: Nikitorowicz, J., Halicki, J. i Muszyńska, J. red. Kultury narodowe na pograniczach. Białystok: Wydawnictwo Uniwersyteckie „Trans Humana”, ss. 309-319.

Nikitorowicz, J. 2011a. Edukacja międzykulturowa w kontekście dylematów integracji imigrantów w warunkach wielokulturowości. W: Paszko, A. red. Edukacja międzykulturowa w Polsce wobec nowych wyzwań. Kraków: Stowarzyszenie Willa Decjusza, ss. 11-29.

Nikitorowicz, J. 2011b. Od Federacji Zespołów Badań Pogranicza do Sto- 
warzyszenia Wspierania Edukacji Międzykulturowej. Pogranicze. Studia Społeczne. XVII, ss. 7-18.

Nikitorowicz, J. 2012. Język domu rodzinnego jako rdzenna wartość kreująca tożsamość międzykulturową. Wychowanie w Rodzinie. 5, ss. 67-82.

Nikitorowicz, J. 2013a. Dylematy patriotyzmu, nacjonalizmu i ustawicznie kształtującej się tożsamości. Wprowadzenie do książki. W: Nikitorowicz, J. red. Patriotyzm i nacjonalizm: Ku jakiej tożsamości kulturowej? Kraków: Oficyna Wydawnicza „Impuls”, ss. 14-26.

Nikitorowicz, J. 2013b. Tożsamość - twórczy wysiłek ku patriotyzmowi. W: Nikitorowicz, J. red. Patriotyzm i nacjonalizm: Ku jakiej tożsamości kulturowej? Kraków: Oficyna Wydawnicza „Impuls”, ss. 29-49.

Nikitorowicz, J. 2014a. Wielokulturowość - Pogranicze - Człowiek pogranicza. Ku paradygmatowi współistnienia, zachowania i kreowania pokoju. Drohiczyński Przegląd Naukowy. Wielokulturowe Studia Drohiczyńskiego Towarzystwa Naukowego. 6, ss. 171-189.

Nikitorowicz, J. 2014b. Zadania edukacji międzykulturowej w kontekście problemów wielokulturowego świata. Studia Kulturowo-Edukacyjne. IX (1), ss. 6-25.

Nikitorowicz, J. 2015a. Edukacja międzykulturowa wobec mitotwórczej apologetyki w kształtujących się społeczeństwach wielokulturowych. W: Komorowska-Zielony, A. i Szkudlarek, T. red. Różnica. Edukacja. Inkluzja. Gdańsk: UG, ss. 147-160.

Nikitorowicz, J. 2015b. Ku jakim strategiom w edukacji międzykulturowej w kontekście współczesnych problemów wielokulturowości? Pogranicze. Studia Społeczne. XXV, ss. 25-40.

Nikitorowicz, J. 2016. Wartość dialogu międzykulturowego w przezwyciężaniu konfliktów na pograniczach kulturowych. Multicultural Studies. T. I, ss. $53-63$.

Nikitorowicz, J. 2017a. Etnopedagogika w kontekście wielokulturowości i ustawicznie ksztattującej się tożsamości. Kraków: Oficyna Wydawnicza „Impuls".

Nikitorowicz, J. 2017b. Polityka edukacyjna w kontekście potrzeby nabywania kompetencji międzykulturowych. Pogranicze. Studia Społeczne. XXX, ss. 7-19.

Nikitorowicz, J. 2019. Pedagogika międzykulturowa w rewitalizacji heterologii w warunkach zróżnicowania kulturowego. Przegląd Pedagogiczny. 1, ss. 11-20.

Nikitorowicz, J. and Żyłkiewicz-Płońska, E. 2017. Identity in Ecological 
Settings. The Theory of Multidimensional Identity. Kultura i Edukacja. 4 (118), ss. 9-20.

Ogrodzka-Mazur, E. 2007. Kompetencja aksjologiczna dzieci w młodszym wieku szkolnym. Studium porównawcze środowisk zróżnicowanych kulturowo. Katowice: UŚ.

Ogrodzka-Mazur, E. 2012. Pogranicze jako przestrzeń aksjologicznego (nie) współistnienia - ku wykluczaniu kulturowemu. Ruch Pedagogiczny. 4, ss. 33-41.

Ogrodzka-Mazur, 2013. (Nie)obecność patriotyzmu w świadomości aksjologicznej młodego pokolenia Polaków. „Przesuwanie się horyzontu aksjologicznego" czy kryzys w wartościowaniu? W: Nikitorowicz, J. red. Patriotyzm i nacjonalizm: Ku jakiej tożsamości kulturowej? Kraków: Oficyna Wydawnicza „Impuls”, ss.106-127.

Ogrodzka-Mazur, E. 2017a. [recenzja]. W: Nikitorowicz, J. Etnopedagogika $w$ kontekście wielokulturowości i ustawicznie ksztattujacej się tożsamości. Kraków: Oficyna Wydawnicza „Impuls”, s. IV (okładki).

Ogrodzka-Mazur, E. 2017b. Między etnicznością a integracją. Strategie kulturalizacyjne przyjmowane przez społeczności szkół z polskim językiem nauczania. Lubelski Rocznik Pedagogiczny. 36, ss. 61-79.

Ogrodzka-Mazur, E. 2018. Intercultural Education in Poland: Current Problems and Research Orientations. Kultura i Edukacja. 2, ss. 65-82.

Ogrodzka-Mazur, E., Klajmon-Lech, U. i Różańska, A. 2014. Tożsamość kulturowa, religijność i edukacja religijna postrzegana z perspektywy społeczności szkót z polskim językiem nauczania $w$ wybranych krajach europejskich. Cieszyn - Toruń: Wydział Etnologii i Nauk o Edukacji Uniwersytetu Śląskiego, Wydawnictwo Adam Marszałek.

Olbrycht, K. 2000. Prawda, dobro i piękno w wychowaniu człowieka jako osoby. Katowice: UŚ.

Olbrycht, K. 2019. Edukacja kulturalna jako edukacja do wzrastania w człowieczeństwie. Katowice: UŚ.

Ostrowska, U. 2019. Wartości patriotyzmu na tle historycznym. Filozofia Edukacji. 1, ss. 33-56.

Paleczny, T. 2019. Międzykulturowe typy tożsamości - pomiędzy integracją a asymilacją. Relacje Międzykulturowe. 1 (5), ss. 11-33.

Przybysz, P.J. 2007. Stereotyp a tożsamość narodowa. Kilka uwag na marginesie książki H. Sienkiewicza „Ogniem i mieczem”. W: Szwed, R. red. Dylematy tożsamości zbiorowych. Przyczynek do rozważań nad tożsamościq ukraińska, polska i europejska. Lublin: KUL, ss. 79-98. 
Rembierz, M. 2017a. Uczenie się pluralizmu i kształtowanie tożsamości religijnej w kontekście kulturowych i światopoglądowych odmienności - między tradycyjnym zróżnicowaniem a współczesnym pluralizmem. Politeja. Pismo Wydziału Studiów Międzynarodowych i Politycznych Uniwersytetu Jagiellońskiego. 46, ss. 191-237.

Rembierz, M. 2017b. O uczeniu się pluralizmu w/dzięki pedagogice. Pluralistyczne perspektywy pedagogiki i różnorodne oblicza pluralizmów w krytycznym rozpoznaniu refleksji metapedagogicznej. Studia Pedagogiczne. LXX, ss. 105-153.

Rembierz, M. 2017c. Jagiellonian Ideas in Shaping Cultural Identity, Social Pluralism and Intercultural Relations - Historical Reconnaissance, Ideological Bonds and Educational Postulates of Stefan Swieżawski. In: Korporowicz, L., Jaskuła, S., Stefanovič, M. and Plichta, P. eds. Jagiellonian Ideas Towards Challenges of Modern Times. Kraków: Jagiellonian Library, pp. 345-377.

Rembierz, M. 2017d. Mała szkoła jako wielka sprawa - i szansa - edukacji. Czasopismo Pedagogiczne. 2 (5), ss. 15-53.

Rembierz, M. 2017e. Kultura intelektualna, wątpliwości metodologiczne i refleksja metapedagogiczna w rozwijaniu teorii i praktyki edukacji między kulturowej. Edukacja Międzykulturowa. 2 (7), ss. 37-67.

Rembierz, M. 2018a. Edukacja międzykulturowa jako ćwiczenie duchowe. Pedagogiczne wymiary kształtowania kultury duchowej i rozumienia wartości ponadkulturowych w kontekście zróżnicowania religijnego i pluralizmu światopoglądowego. Edukacja Międzykulturowa. 2, ss. 90-130.

Rembierz, M. 2018b. Spór o koncepcję społeczeństwa i wartość jednostki jako kontekst i wyzwanie dla polskiej myśli pedagogicznej. Polska Myśl Pedagogiczna. 2, ss. 59-90.

Rembierz, M. 2019. Między wielokulturowością „wieży Babel” a zróżnicowanymi kulturowo pograniczami. Pedagogiczne poszukiwania i idee Tadeusza Lewowickiego w zakresie edukacji kształtującej relacje międzykulturowe. Edukacja Międzykulturowa. 2 (11), ss. 40-56.

Różańska, A. 2015. Edukacja religijna młodzieży w warunkach pluralizmu religijnego w wybranych krajach Europy Środkowo-Wschodniej: Polska, Czechy, Stowacja, Wegry) - studium porównawcze. Cieszyn - Toruń: Wydział Etnologii i Nauk o Edukacji Uniwersytetu Śląskiego, Wydawnictwo Adam Marszałek.

Rusek, H. 2019, Edukacja międzykulturowa i antropologia pogranicza: wspólnota źródeł i dróg rozwoju. Edukacja Międzykulturowa. 2 (11), ss. 23-39. 
Sobecki, M. 2016. Komunikacja międzykulturowa w perspektywie pedagogicznej. Studium z pogranicza polsko-litewsko-białorusko-ukraińskiego. Warszawa: ŻAK.

Stróżewski, W. 2013. Ponadkulturowe wymiary dobra, prawdy i piękna. W: Stróżewski, W. Logos, wartość, mitość. Kraków: Znak, ss. 361-388.

Suchodolska, J. 2010. Percepcja ucznia - jako innego - przez nauczycieli. Osobiste i społeczne tło rozwoju kompetencji komunikacyjnych nauczyciela. W: Jasiński, Z. red. Szkoła i nauczyciele wobec problemów edukacji międzykulturowej. Opole: INP UO, ss. 167-181.

Szczepański, J. 2003. Korzeniami wrosłem w ziemię. Ustroń: Galeria „Na Gojach".

Szczepański, M.S. 1996. Ludzie bez ojczyzny prywatnej i edukacja regionalna. W: Lewowicki, T. i Grabowska, B. red. Społeczności Pogranicza - Wielokulturowość - Edukacja. Cieszyn: UŚ - Filia w Cieszynie, ss. 157-175.

Szczepański, M.S. i Śliz, A. 2012. Społeczne przestrzenie konfliktów etnicznych. Górnośląskie Studia Socjologiczne. Seria Nowa. 3, ss. 11-27.

Szczurek-Boruta, A. 2007a. Zadania rozwojowe młodzieży i edukacyjne warunki ich wypetniania w środowiskach zróżnicowanych kulturowo i gospodarczo. Katowice: UŚ.

Szczurek-Boruta, A. 2007b. Edukacja i odkrywanie tożsamości w warunkach wielokulturowości. Szkice pedagogiczne. Katowice - Cieszyn - Kraków: Wydział Etnologii i Nauk o Edukacji Uniwersytetu Śląskiego, Oficyna Wydawnicza „Impuls”.

Szczurek-Boruta, A. 2009. Konflikt - bariera czy szansa w kształtowaniu pozytywnych relacji międzykulturowych. W: Lewowicki, T., Ogrodzka-Mazur, E. i Urban, J. red. Społeczne uwarunkowania edukacji międzykulturowej. Cieszyn - Warszawa - Toruń: Wydział Etnologii i Nauk o Edukacji Uniwersytetu Śląskiego, Wyższa Szkoła Pedagogiczna ZNP w Warszawie, Wydawnictwo Adam Marszałek, ss. 125-138.

Szczurek-Boruta, A. 2011. Edukacyjne konteksty kształtowania poczucia tożsamości kulturowej młodzieży - studia i doświadczenia z pogranicza polsko-czeskiego. Pogranicze. Studia Społeczne. XVII, ss. 141-165.

Szczurek-Boruta, A. 2012. Uczenie się międzykulturowe - ku tożsamości wielowymiarowej i integracji społecznej. Ruch Pedagogiczny. 4, ss. 25-31. Szczurek-Boruta, A. 2013a. Doświadczenia społeczne w przygotowaniu przyszłych nauczycieli do pracy w warunkach wielokulturowości. Toruń: Wydawnictwo Adam Marszałek.

Szczurek-Boruta, A. 2013b. Nauczyciele i kształtowanie kompetencji mię- 
dzykulturowej uczniów. Pogranicze. Studia Społeczne. XXX, ss. 155-169. Szczurek-Boruta, A. 2014. O przygotowaniu nauczycieli do pracy w warunkach wielokulturowości - konteksty, opinie studentów, propozycje. Toruń: Wydawnictwo Adam Marszałek.

Szczurek-Boruta, A. 2017. Tożsamość młodych Polaków mieszkających na pograniczu polsko-czeskim. Pogranicze. Studia Społeczne. XXI, ss. 195-209 .

Szulakiewicz, M. 2010. Kategoria dialogu w refleksji filozoficzna. Paedagogia Christiana. 1 (25), ss. 34-53.

Szulakiewicz, M. 2011. Czas i to, co ludzkie. Szkice z chronozofii i kultury. Toruń: UMK.

Szulich-Kałuża, J. 2016. Kultury narodowe w kontekście europejskości i wielokulturowości w refleksji Leona Dyczewskiego. Roczniki Kulturoznawcze. VII (4), ss. 25-41.

Śliz, A. i Szczepański, M.S. 2015. Wielokulturowość współczesna: terminy, idee, teorie i aktorzy. Górnośląskie Studia Socjologiczne. Seria Nowa. 6, ss. $13-27$.

Śliz, A. 2017. Wielokulturowość: stygmat wspótczesnego świata? Próba analizy socjologicznej. Opole: UO.

Śliwerski, B. 1998. Wspótczesne teorie i nurty wychowania. Kraków: Oficyna Wydawnicza „Impuls”.

Śliwerski, B. 2010. Myśleć jako pedagog. Sopot: GWP.

Śliwerski, 2013. Pedagogika jako (nie-)gorsza INNA nauka. Studia Edukacyjne. 28, ss. $57-84$.

Świątkiewicz, W. 1991. Tożsamość kulturowa - ujęcie socjologiczne. W: Świątkiewicz, W. i Wódz, K. red. Tożsamość kulturowa mieszkańców starych dzielnic miast Górnego Ślaska. Wrocław: Zakład Narodowy im. Ossolińskich, ss. 9-17.

Świątkiewicz, W. 2001. Tożsamość kulturowa regionu jako wartość społeczna. W: Barański, M. red. Zagtębie Dąbrowskie w poszukiwaniu tożsamości regionalnej. Katowice: UŚ, ss. 81-89.

Weil, S. 1961. Zakorzenienie i inne fragmenty. Wybór pism. Tłum. Konarska-Łosiowa, K., Wielowieyski, A., Witkowska, M. Wybór i przedmowa Wielowieyski A., Kraków: Znak (Biblioteka „Więzi”).

Wieczorek, K. 2017, Opuścić bezpieczne schronienie. Problem obcości w świetle filozofii dialogu. Ethos. 117, ss. 76-103.

Wielecki, K. 2014. Między różnorodnością kulturową i rozpadem tożsamości. Uniwersyteckie Czasopismo Socjologiczne. 9, ss. 41-52. 
Wielecki, K. 2019. Wstęp do wydania polskiego. Dobra socjologia w trudnym świecie. Znaczenie teorii Margaret S. Archer w czasach kryzysu cywilizacji i socjologii. W: Archer, M.S. Kultura i sprawczość. Miejsce kultury w teorii społecznej. Warszawa: NCK, ss. 13-65.

Wierzbicki, A.M. 2008. Polskość - ale jaka? W: Wierzbicki, A.M. »...na ziemi w lublinie... « Felietony społeczno-kulturalne. Lublin: Norbertinum, ss. 222-230.

Wiśniewski, R. 2016. Wartość absolutna a problemy moralnej praxis. W: Janeczek, S. i Starościc, S. red. Etyka. Część II. Lublin: KUL, ss. 597-612. Witkowski, L. 1990. W stronę edukacji (dla) pogranicza (pedagogiczne „Bachtinalia”). Kwartalnik Pedagogiczny. 4, ss. 47-66

Witkowski, L. 1995. Ambiwalencje tożsamości z pogranicza kulturowego. W: Urlińska M.M. red. Edukacja a tożsamość etniczna. Toruń: UMK, ss. 11-23.

Witkowski, L. 2000. Uniwersalizm pogranicza. O semiotyce kultury Michała Bachtina w kontekście edukacji. Toruń: Wydawnictwo Adam Marszałek. Valčo, M. 2018. Sekularizácia ako výzva pre tradičné náboženstvá Európy podla Charlesa Taylora. Historia Ecclesiastica. 9 (1), ss. 173-190.

\section{Between being rooted in the heritage of tradition and the openness of/to borderlands. On Jerzy Nikitorowicz's shaping of "intercultural identity" and some educational traces in his research}

Abstract: What has been explored and emphasized in the pedagogical research of Jerzy Nikitorowicz is the experience of being rooted in the heritage of tradition and the experience of the "borderland man". Having elaborated theoretically mature and practically useful intercultural pedagogy as well as the concept of "intercultural identity", Nikitorowicz affirms the attitude of the "borderland man", who is open to the diversity of cultures, religions and languages. This takes place along with the awareness of conflict raising tensions, which cannot be avoided in the borderland dynamics. Moreover, the "between" situation, typical of the experiencing of values by the borderland man and of shaping "intercultural identity" requires specific "praise of inconsistency". In the borderland situation, something can be "at the same time", "simultaneously" and "in parallel": at the same time what it is (which has a particular shape of identity) and something else - something on the borderline of the one and the other (or the third and still the next) selfhood. Being familiarized with the complexity of borderlands, to a certain extent, one is 
prepared to face the views that are different than one's own. Those different views, especially the ones concerning values, appear as not obvious and expressing a different (hard to understand and accept) standpoint. Therefore, what appears as not obvious should be reliably confronted with one's own obviousness, undertaking the risk that it will become questionable and will lose the features of obviousness. One ought to conduct intellectual struggle against the insufficiency of cognitive abilities not to be affected by cognitive disorientation, not to acquire learned helplessness and not to yield to uncertainty. Borderlands are not "far away" in distant land ends - their presence and features, e.g. dynamic systems of values, comply with various spheres of human existence, as a factor that helps to understand the fundamental "human matters'. According to Nikitorowicz, the identity creating values of the borderland enhance the forming of subjectivity and self-effectiveness of "an individual who develops and self-manages on the basis of traditions and cultural heritage". At the same time, carrying the memory of the complexity of borderland experiences, Nikitorowicz as a "borderland man" indicates such duality: "On the one hand, [the borderland] brings about the feeling of social and cultural (family, religious, [...], ethnic) identity, but on the other hand it causes threat, loss of the feeling of safety, the fear of the intolerance of the dominating group" (Nikitorowicz, 1995, p. 19). From the standpoint of intercultural education, Nikitorowicz puts forward a postulate of reading anew the Polish traditions of cultural borderlands in the context of the current cultural and social challenges. Aiming at the elaboration of some more general theoretical approaches to the Other, borderlands and intercultural relations - such approaches that will complement intercultural pedagogy - Nikitorowicz suggests the revitalization of heterology, as a science and knowledge concerning the Other, and points to its necessity in the complex nature of cultural diversification.

Keywords: rooting, heritage of tradition, openness, borderlands, intercultural education, "intercultural identity" 